\title{
Planning of Higher Education Information Technology Strategy Using TOGAF (A Case Study at AMN Cilacap)
}

\author{
O T Prayitno ${ }^{* 1,2}$ \\ ${ }^{1}$ Magister Teknik Informatika, Universitas Atma Jaya Yogyakarta, Yogyakarta, \\ Indonesia 55281 \\ ${ }^{2}$ Akademi Maritim Nusantara Cilacap, Cilacap, Indonesia
}

E-mail: otegoohp@gmail.com ${ }^{1}$

Masuk: 18 Juni 2019, direvisi: 28 Agustus 2019, diterima: 30 Agustus 2019

\begin{abstract}
Teknologi informasi yang berkembang seiring dengan pesatnya peran komunikasi melalui Internet membuat teknologi dan sistem informasi memiliki posisi yang sangat vital bagi keselarasan bisnis sebuah lembaga termasuk lembaga pendidikan tinggi. Perencanaan strategis sektor ini memiliki tujuan untuk menyusun dasar/pedoman dalam membangun dan mengembangkan teknologi dan sistem informasi untuk mendukung tujuan organisasi dan meningkatkan keunggulan kompetitif yang semakin ketat. Maka, integrasi antara bisnis dan teknologi informasi menjadi penting untuk mendukung daya saing lembaga. Tanggung jawab dari Enterprise Architecture (EA) adalah menyediakan sistem informasi yang tepat dan cepat berdasarkan permintaan bisnis lembaga. Standar dan model yang tepat diperlukan oleh lembaga pendidikan tinggi untuk meningkatkan keselarasan strategi bisnis dan teknologi informasi. Penelitian ini akan menelusuri permasalahan yang dihadapi oleh AMN Cilacap dan memberi masukkan pengembangan teknologi dan sistem informasi yang dibutuhkan menggunakan EA dengan metodologi The Open Group Architecture Framework (TOGAF). TOGAF menyediakan metode dan alat untuk membantu dalam penerimaan, produksi, penggunaan, dan pemeliharaan arsitektur perusahaan.
\end{abstract}

Keywords: EA; TOGAF; perencanaan strategis; pendidikan tinggi; sistem informasi

\begin{abstract}
Information technology that develops along with the rapid role of communication through the Internet makes technology and information systems have a position that is vital for the business alignment of an institution including higher education institutions. The strategic planning of this sector has a goal to develop the basis / guidelines in developing and developing information technology and systems to support organizational goals and increase increasingly competitive competitive advantage. Thus, the integration between business and information technology becomes important to support the competitiveness of institutions. The responsibility of Enterprise Architecture (EA) is to provide an accurate and fast information system based on the business demands of the institution. Appropriate standards and models are needed by higher education institutions to improve the alignment of business strategies and information technology. This study will explore the problems faced by AMN Cilacap and provide the development of information technology and systems needed to use EA using the Open Group Architecture Framework (TOGAF) methodology. TOGAF provides methods and tools to assist in the receipt, production, use and maintenance of corporate architecture.
\end{abstract}


Keywords: EA; TOGAF; strategic planning; higher education; information systems

\section{Introduction}

Strategic planning of information technology development and information systems in higher education is derived from the institution's strategic planning globally. Everywhere nowadays, businesses experience changes that are very fast and significant. These changes include the ability of small-scale business companies that are able to compete effectively with large business companies because they are more agile. The use of information technology is a fundamental problem for every business today. In essence, IT can change the basic nature of an industry. According to Luftman [1], business alignment and IS / IT are the extent to which the IS / IT strategy supports and is supported by business strategies.

Effective and efficient use of information technology requires aligning IT strategies with business strategies [1]. That harmony is explained in Figure 1. There are four domain alignment of this model, namely: Business Strategy, IT Strategy, Organizational Infrastructure and IT Infrastructure. Of the twelve perspectives, we will focus on the four most common perspectives, namely strategy execution, technological potential, competitive potential and service level.

Higher Education Institutions (PT) have different business domains than other business organizations / institutions. The role of information technology is preferred in this process. So complex and scale, information technology management in PT is worthy of being aligned with the company. Therefore, special planning and design is needed to ensure that information technology is implemented according to the institution's strategic goals and plans and can be optimally used by the institution itself. In Indonesia, the vision and mission of the PT must be in harmony with the Tri Dharma of Higher Education, namely: education, research and community service [2].

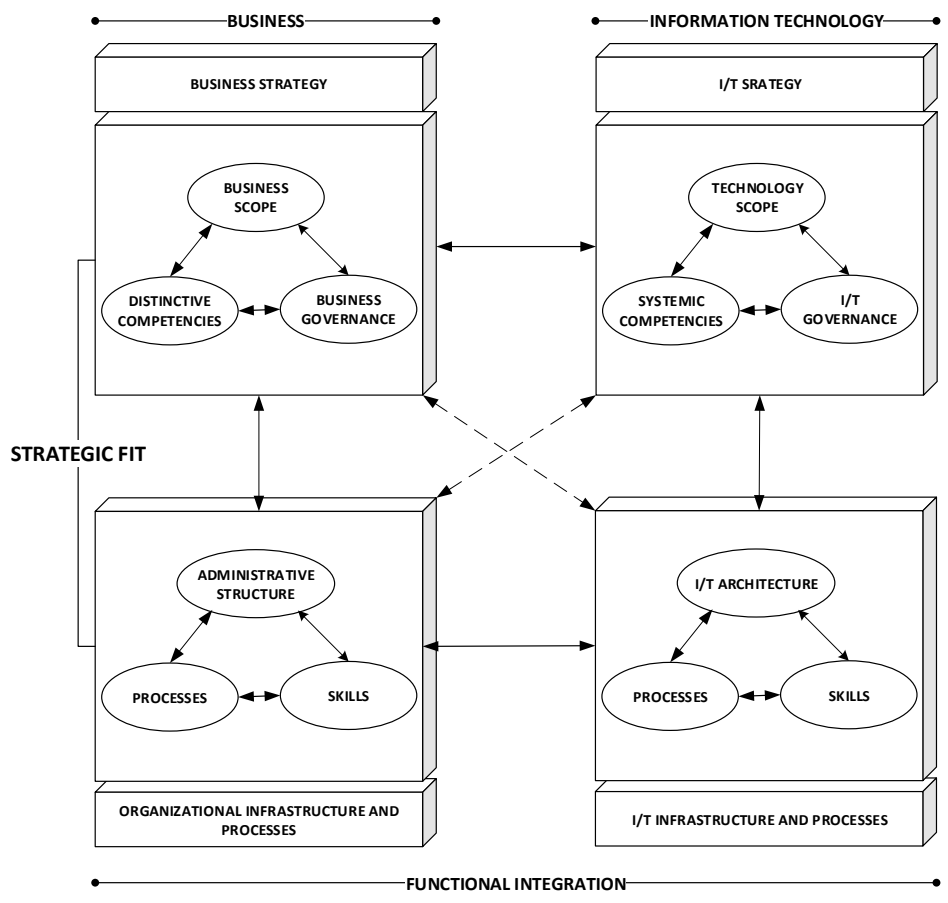

Figure 1. Alignment of Business Integration

So far, the development of information technology and systems carried out at the Cilacap Nusantara Maritime Academy is carried out partially / sporadically. There is no plan based on research or standard design planning. In fact, the role of technology and information systems in the era of Industrial Revolution 4.0 has become a basic and very vital necessity in responding to competition, 
providing customer satisfaction with excellent service and certainly is to answer the needs of institutions for future business interests.

The purpose of this information system strategic planning is to provide a reference in developing information systems in order to achieve organizational goals and competitive advantages with other maritime universities as well as to offer competitive advantages with other universities so that AMN Cilacap has the attraction to get prospective students and other parties can work with AMN Cilacap. Organizations with the right planning for their EA and other information systems (IS) will create global competition for all products and services, and have a big advantage over organizations that do not have them. Good EA and Information Technology (IT) help run a successful business model [3].

The Enterprise Architecture Framework (EAF) is used to design a short, medium and long term strategic plan. This is useful for making institutions anticipate the increasing complexity of business processes that occur in addition to improving service to clients and competitiveness with other institutions. The function of EAF is to model business and information technology. The choice of the EAF model used depends on the perspective, because each has different scope and activities [4]. This is the way of institutions to answer challenges in increasing their competitiveness. With EA, the institution has a goal to form an integrated environment in a system. EA provides a global understanding of all aspects of business, being a controlling-controlling bridge and business environment through business processes, organizational units, roles and responsibilities of information technology that underlie their dependability in all business activities [5].

EA helps organizations to define business architecture, information systems and technology that are able to align business strategies with information technology. Designing a good EA must consider various perspectives on aligning information technology with the business needs of each organization because of the domain of architecture and can describe the business components and information technology that need to be reconciled, how to synchronize and measure alignment Linking the company's strategic plan with data architecture, the application architecture and the company's technical architecture the result is a corporate information system [3].

The world of education is currently heavily affected by changing trends and the science of education and technology. Not only globalization, but also now is the era of Industrial Revolution 4.0, where the role of information and communication technology supported by the advancement of artificial intelligence changes many things in the world of higher education, including interdisciplinary teaching, research and innovation methods. Including services to stakeholders and management decision making.

An integrated system is needed by organizations to support their business processes. The larger the organization, the more complex business processes that occur within it. The more complex the process will become a separate obstacle if the existing system is still running separately/separately. The role of information systems here is to be a means to help an organization in carrying out integrated business processes, improve service quality to consumers and improve competitiveness with other organizations, especially in the maritime higher education sector. However, the agency's strategic plan includes a strategic plan on aspects of information technology - influenced by the economic environment and reduced budget [6].

\section{Theoretical Framework}

John A. Zachman defines architecture as a set of design artifacts, or descriptive representations, that are relevant for describing objects in such a way that they can be produced with requirements (quality) and maintained during the useful period (change) [7].

The company / institution information system is a principal component of the company's architecture. Applying and changing its information system also requires changes in its architecture. Conversely, any changes to the architecture will have an impact on the information system. The result is the next generation company information system must be seen in the context of this new reality [8].

According to IBM, the basic definition of EA is an architectural discipline that combines strategic business and information technology goals with opportunities for change and regulates the initiative of change that results. It provides an understanding that the scope of EA does not only focus on strategic 
business planning, but rather on how to unite and harmonize the organization's business strategies with IT organizations that aim to change and manage the change initiatives that produce them. The main focus of EA is to guide strategic planning in the context of portfolios and direct change that is aligned with organizational goals in general. EA provides appropriate changes that are applied in the right way [9].

There are four types of EA management patterns that have been identified. First, the methodology pattern (M-Pattern), which defines the steps that must be taken to overcome the problem given. Second, the pattern of view (V-Pattern), provides the language used by one or more M-Patterns and then presents the stored data with one or more information models. Third, the information model pattern (I-Pattern) provides a basic model for data visualized by one or more V-Pattern models. Fourth is Anti-Pattern. Anti-Pattern is an EA document management solution and is proven not to be useful for breaking dead ends [10].

Of the many EA models, TOGAF is the most widely used to develop strategic plans. This is based on the definition of architecture according to ISO 42010/2011 "The fundamental organization of a system, which is contained in its components, their relationships with each other and the environment, and the principles that govern the design and evolution."[11]. TOGAF itself is short of The Open Group Architecture Framework and was developed by The Open Group since 1995 [12]. A brief explanation is a comprehensive architecture framework and methodology that allows the design, evaluation and implementation of the right architecture for a company [13]. TOGAF is more flexible because it can be used with a series of work results from other frameworks, or can even be used in conjunction with the Zachman framework [14]. ADM is designed to allow adjustments by individuals. This is so that TOGAF users will use ADM TOGAF as a guide in designing the architecture [15]. Four domains of TOGAF are [16][17] :

a. Business architecture: architecture that explains how business processes are aligned with the goals of the organization / institution. Included: business strategy, government, organization and key business processes

b. Data architecture: provides an overview of how to store, manage and access agency data which is a structure of the set of physical data and organizational logic and data management resources.

c. Application architecture: describes specifically how applications are designed and those applications can interact with each other.

d. Technology architecture: provides an overview of the hardware and software infrastructure supporting those applications and their interactions.

The four domains are shown in Figure 2.

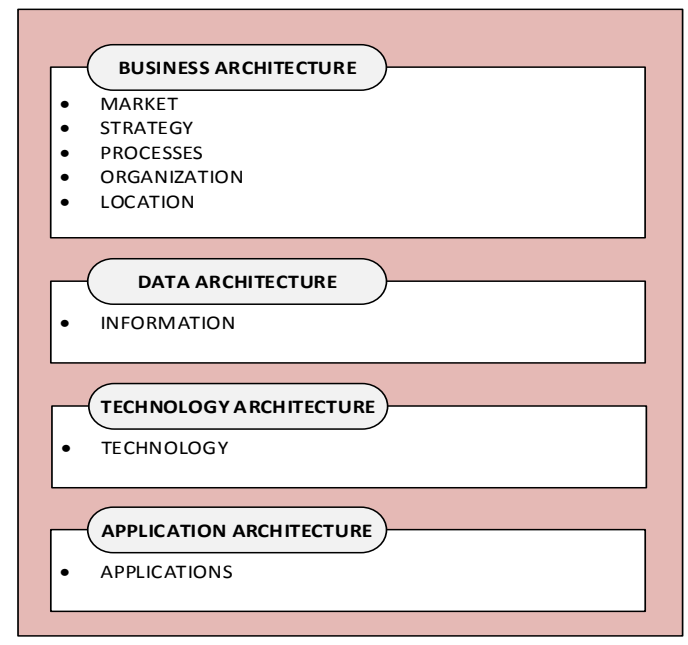

Figure 2. ADM TOGAF Stages 
TOGAF provides methods and tools used to plan, build, design and manage the development and implementation of EA because TOGAF provides all of them in detail using the Architecture Development Method (ADM) [17]. TOGAF ADM is a methodology that describes a repetitive method for EA development and more clearly shown in Figure 3 [18]. An iterative model based on good implementation allows the acceptance, use, and maintenance of corporate architecture using $\mathrm{ADM}$ as the main method of development [19]. The main components of TOGAF provide architectural guidance at levels [20]:

1. Providing a phase of architectural development (business, information systems and technology).

2. Gives narration to each architectural phase that describes the phase in terms of objectives, approaches, inputs, steps, and outputs. The input and output sections provide definitions of the structure and results of architectural content.

3. Provide a cross-phase summary that includes management requirements / needs.

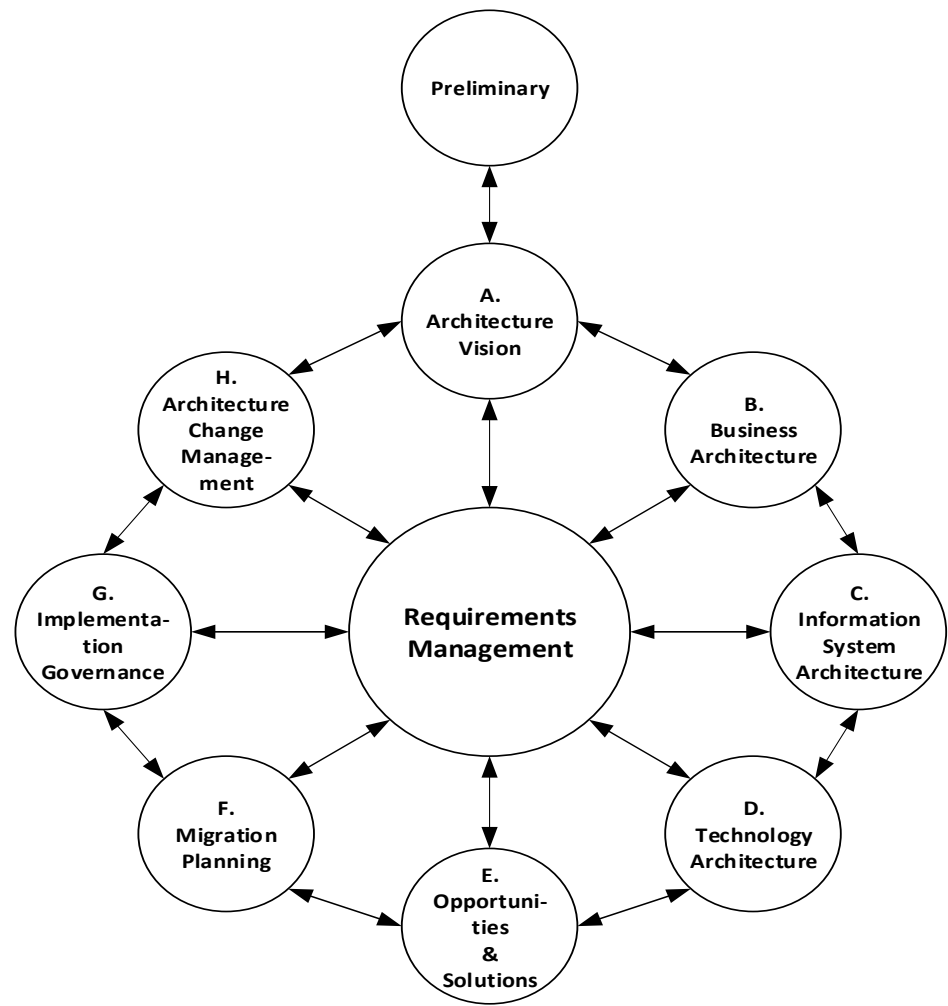

Figure 3. ADM TOGAF Cycle [12]

\section{Methodology}

In this study, data is used in the form of primary data and secondary data. Primary data was obtained from interviews and direct observations with related institutions, namely AMN Cilacap. While secondary data is obtained from collecting documents or reports from resource persons. Analysis and description tools are also used. The analytical tool used in the Business Modeling phase is Porter's Value Chain Diagram. There are two approaches that can be used for the basis, namely classical and object oriented approaches. Classical approaches include: Hierarchical Diagrams, Business Process Models and Notations (BPMN), Data Flow Diagrams (DFD) Entity Relationship Diagrams (ERD). The departure of the object oriented approach includes: Unified Modeling Language (UML) [7]. Figure 4 shows the framework of the research carried out in this study.

In this study, data is used in the form of primary data and secondary data. Primary data was obtained from interviews and direct observations with related institutions, namely AMN Cilacap. While secondary data is obtained from collecting documents or reports from resource persons. 
Analysis and description tools are also used. The analytical tool used in the Business Modeling phase is Porter's Value Chain Diagram. There are two approaches that can be used for the basis, namely classical and object oriented approaches. Classical approaches include: Hierarchical Diagrams, Business Process Models and Notations (BPMN), Data Flow Diagrams (DFD) Entity Relationship Diagrams (ERD). The departure of the object oriented approach includes: Unified Modeling Language (UML) [7]. Figure 4 shows the framework of the research carried out in this study.

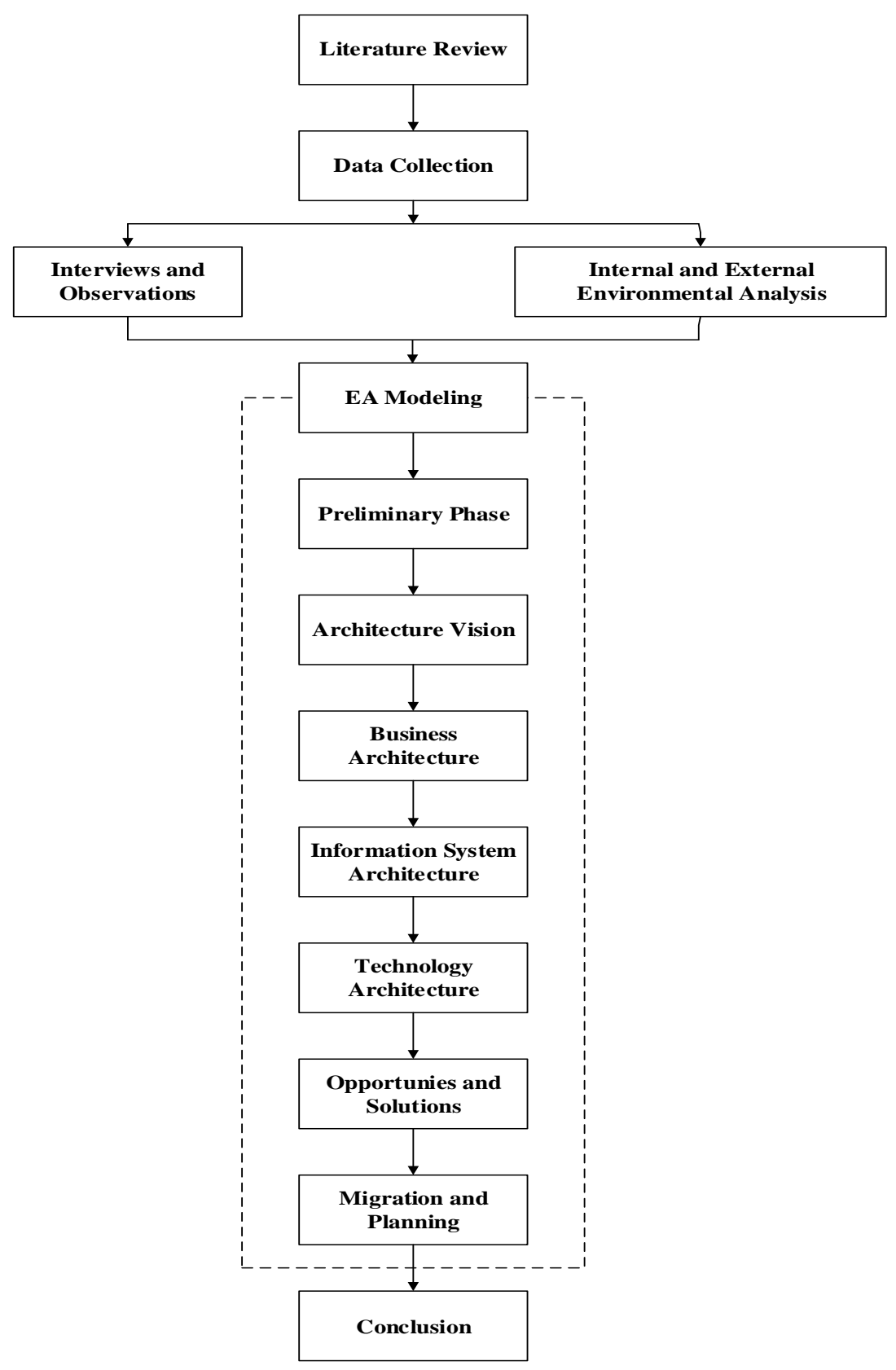

Figure 4. Research Framework

Analysis of the internal environment of the activity is used to understand the condition of the situation in the internal environment of the activity. The analysis techniques are:

1. SWOT Analysis (Strength, Weakness, Opportunity and Threat) 
To analyze the strengths and weaknesses of the Cilacap AMN, the opportunities and challenges from outside to determine the most appropriate strategy for AMN Cilacapin carrying out its organizational wheels are explained in Table 1.

2. Value chain analysis

That is analyzing business processes that are running by using Porter's Value Chain. Porter's value chain is used to identify the main activities and supporting activities at AMN Cilacapas shown in Figure 5. Both of these activities must ultimately support the vision and mission of the institution. Porter's Value Chain facilitates the analysis of processes within a company but does not provide an easy mechanism to link them with high-level business goals [21].

There are two activities carried out at the Cilacap Nusantara Maritime Academy, namely:

1. Main activities: PTB, Academic, Graduates and Research and Community Service

2. Supporting activities: Procurement of Facilities dan Infrastructure, HR Management, Financial Management and QMR.

Table 1. AMN Cilacap SWOT Analysis

\begin{tabular}{|c|c|c|}
\hline & STRENGHTS & WEAKNESS \\
\hline 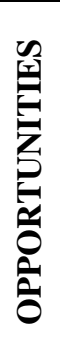 & $\begin{array}{l}\text { 1. The development of ICTs to support the } \\
\text { Tri Dharma of Higher Education is } \\
\text { increasingly being improved } \\
\text { 2. Improve IT division performance in the } \\
\text { management, development and } \\
\text { maintenance of IS / IT. } \\
\text { 3. Improve accurate and fast information } \\
\text { services to support customer satisfaction }\end{array}$ & $\begin{array}{l}\text { 1. Add human resource in the IT field. } \\
\text { 2. Integrating information systems in one } \\
\text { centralized database } \\
\text { 3. Improve internet accessibility for } \\
\text { cadets and academics } \\
\text { 4. Provide training to lecturers and staff } \\
\text { staff in improving mastery of IT and } \\
\text { services }\end{array}$ \\
\hline 䎹 & $\begin{array}{l}\text { 1. Improve the quality of human resources } \\
\text { in the IT field by including in national / } \\
\text { international standardized IT training. } \\
\text { 2. Improve the function and reliability of } \\
\text { information systems for academic } \\
\text { services both client and server. }\end{array}$ & $\begin{array}{l}\text { 1. Improve information that can be } \\
\text { conveyed to the wider community } \\
\text { through the web. } \\
\text { 2. Improve accessibility of information } \\
\text { for parents / guardians. }\end{array}$ \\
\hline
\end{tabular}

From these two activities, derivative business processes can be formulated as shown in Figure 6 and Figure 7.
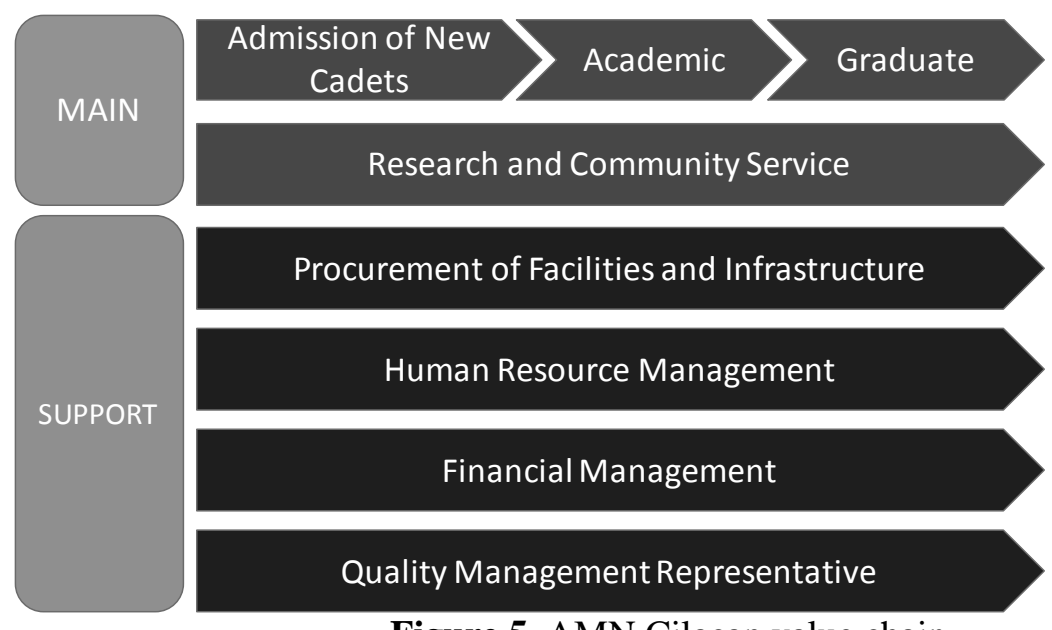

Financial Management

Quality Management Representative

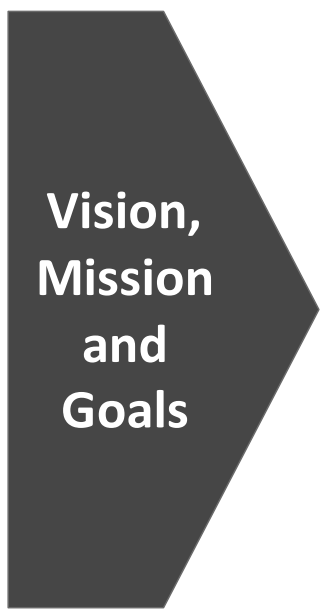

Figure 5. AMN Cilacap value chain 


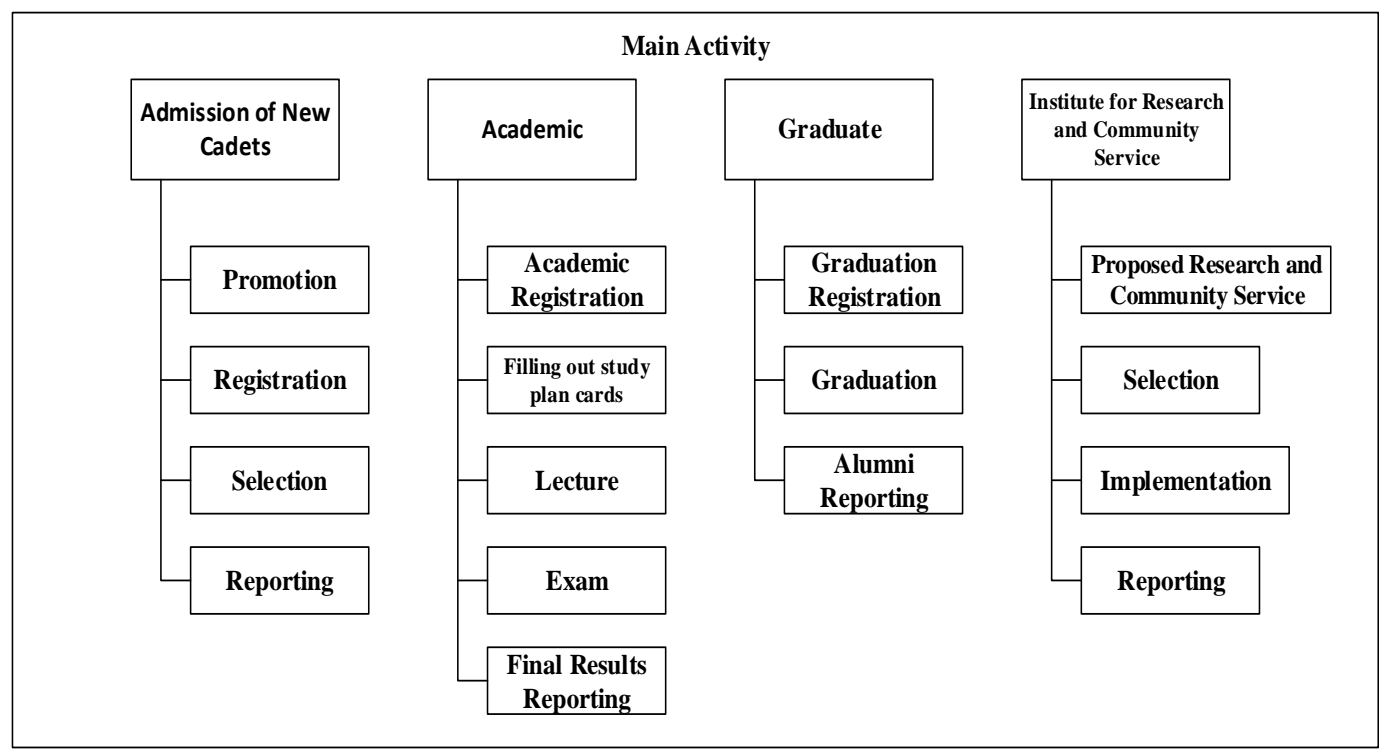

Figure 6. Main Sub Process

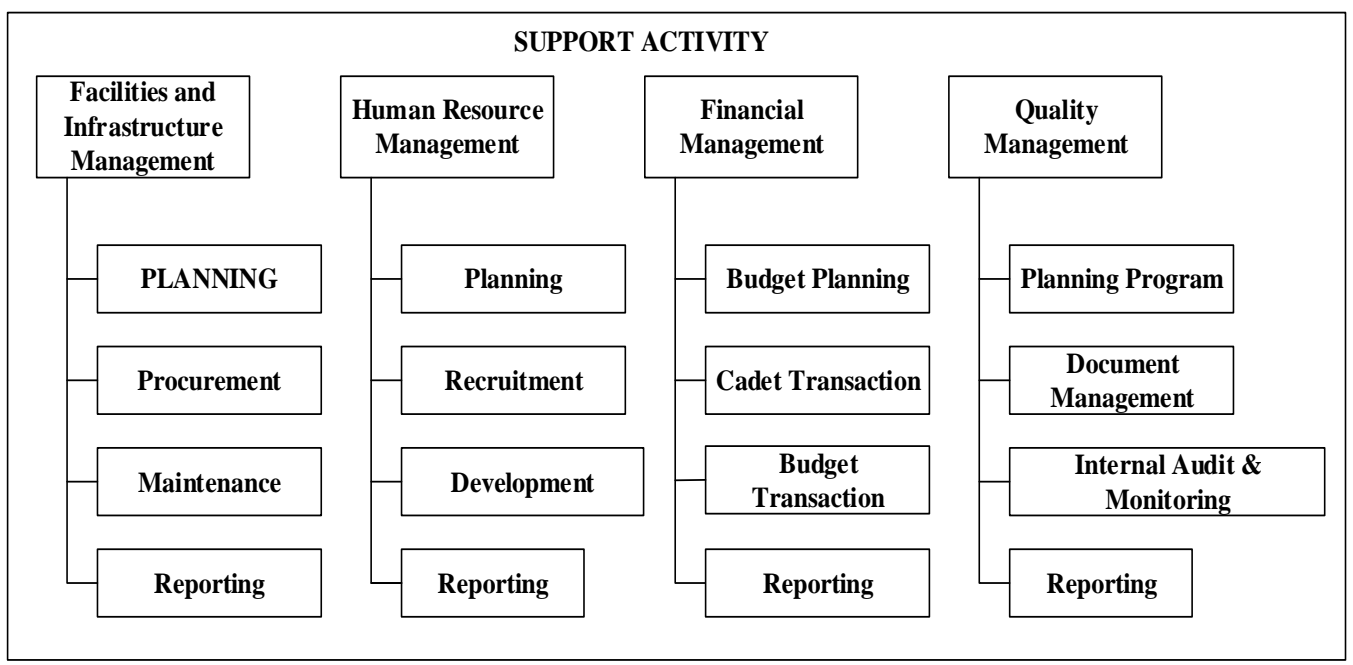

Figure 7. Supporting Sub Process

Analysis of information systems that are currently running, found there are 3 systems, namely: Academic Information System (SIKA), new cadets acceptance information system (PTB) and alumni information system, as described in Table 2.

Table 2. Current System

\begin{tabular}{|c|c|c|}
\hline $\begin{array}{c}\text { Information } \\
\text { Systems }\end{array}$ & Activities carried out & Information \\
\hline $\begin{array}{l}\text { New Cadets } \\
\text { Acceptance } \\
\text { Information } \\
\text { System } \\
\text { (PTB) }\end{array}$ & $\begin{array}{l}\text { - Registration of prospective new } \\
\text { cadets } \\
\text { - Print exam cards }\end{array}$ & $\begin{array}{l}\text { The total PTB selection } \\
\text { system online has not been } \\
\text { implemented due to some } \\
\text { current considerations. Only } \\
\text { when filling out the } \\
\text { registration form can it be } \\
\text { done online. }\end{array}$ \\
\hline
\end{tabular}




\begin{tabular}{|c|c|}
\hline Alumni & $\begin{array}{ll}\text { - } & \text { Tracer study } \\
\text { - } & \text { Data alumni }\end{array}$ \\
\hline $\begin{array}{l}\text { Academic } \\
\text { Information } \\
\text { System } \\
\text { (SIKA) }\end{array}$ & $\begin{array}{l}\text { - } \text { Fill in KRS (for level I and II are } \\
\text { still packages) } \\
\text { - } \quad \text { Schedule lectures and practices } \\
\text { - } \text { Print attendance, KRS, KHS and } \\
\text { value transcripts } \\
\text { - Cadets see KHS } \\
\text { - Cadets see the transcript of the } \\
\text { - } \text { Score } \\
\text { Value management }\end{array}$ \\
\hline
\end{tabular}

The web for AMN Cilacapalumni is used to collect alumni data and alumni tracer studies.

SIKA at AMN Cilacap includes many important modules, such as filling up the KRS

with value transcripts that accommodate transactions from both institutions and cadets. However, SIKA has not been integrated with other systems such as PTB and finance

From Table 2, it can be seen that there is still very limited use of information systems in the business processes running on AMN Cilacap. Of the three processes, there are still some aspects that still need to be improved and developed, including developing other business processes so that they can be integrated in an information system that will help achieve the vision and mission of the institution and increase its competitiveness.

\section{Results and Discussion}

\subsection{The proposed architecture}

a. The validity of data collected by the researcher is tested with Structural Equation Modeling (SEM). AMN Cilacap New Student Admission (PTB) architecture includes the registration process, the entrance examination process and the process of announcing the results of selection and reporting.

b. Academic Business Architecture which covers the academic registration process, the process of filling in the KRS, the lecture process, the process of implementing the exam and the value reporting process.

c. Graduate Business Architecture which includes the process of registering and releasing graduates and tracer studies.

d. Research \& Community Service Business Architecture which includes the process of submission and selection, implementation and reporting processes.

e. The Financial Architecture includes the process of setting budgets, paying cadets, the budget disbursement process, and the financial reporting process.

f. Employee Business Architecture includes the recruitment process, HR development process and reporting process.

g. Infrastructure Architecture Infrastructure which covers the procurement process, inventory process of goods and maintenance processes.

\subsection{Information System Architecture}

This stage determines the data architecture and application architecture. The data architecture describes the organizational structure of the logical data assets and management of organizational resource data using ERD. Information System Architecture includes:

1. Data Architecture 
At this stage, it emphasizes more on how data architecture is developed, data is integrated with each other, determining the data needed and data used to support business processes at the stage of defining business models. The data architecture describes entities, attributes, and relations. Following are the steps in defining data architecture:

1. Defining prospective data entities by looking at the business architecture modeling stage and the information architecture modeling stage.

2. Establish entities to be used in each business process.

3. Define each entity to be used and document it.

4. Connecting between data entities with detailed business functions.

The first step in defining data architecture is to define prospective data entities by registering candidate data entities using a Data Component Catalog that contains data sets that exist in the organization, as shown in Table 3.

Table 3. Entities Candidate

\begin{tabular}{|c|c|}
\hline Business Activity & Data Entity Candidate \\
\hline \multirow[t]{5}{*}{ Admission of New Cadet } & Candidate Entity \\
\hline & Entity Exam Schedule \\
\hline & Questions Bank Entity \\
\hline & Staged Entity \\
\hline & Entity Exam Results \\
\hline \multirow[t]{20}{*}{ Academic } & Candidate Entity \\
\hline & Cadet Entity \\
\hline & Lecturer Entity \\
\hline & Parent / Guardian Entity \\
\hline & Academic Advisor Lecturer Entity \\
\hline & Study Program Entities \\
\hline & Entity Status Cadet \\
\hline & Curriculum Entity \\
\hline & Entity Subjects \\
\hline & Study Plan Entity Card \\
\hline & Entity Schedule Card Study Plan \\
\hline & Lecture Schedule Entity \\
\hline & Youth Attendance Entity \\
\hline & Lecturer Attendance Entity \\
\hline & Entity Final Examination Schedule \\
\hline & End Result Entity \\
\hline & Study Result Card Entity \\
\hline & Guidance Entity \\
\hline & Final Project Entity \\
\hline & Final Assignment Session Schedule Entity \\
\hline \multirow[t]{6}{*}{ Graduate } & Cadet Entity \\
\hline & Entity Status Cadet \\
\hline & Graduation Registration Entity \\
\hline & Alumni Entity \\
\hline & Tracer Study Entity \\
\hline & Tracer Study Outcome Entity \\
\hline Research and Service & Lecturer Entity \\
\hline \multirow[t]{6}{*}{ Community } & Study Program Entities \\
\hline & Research Entity \\
\hline & Review Entity \\
\hline & Research Entity \\
\hline & Service Entity \\
\hline & Period Entity \\
\hline
\end{tabular}




\begin{tabular}{ll}
\hline Business Activity & Data Entity Candidate \\
\hline Finacial & BANK Entity \\
& Cost Entity \\
Installment Entity & Prospective Cadet Transaction Entity \\
& Cadet Transaction Entity \\
& Employee Salary Entity \\
& Entity Work Plan and Budget \\
& Funds Disbursement Entity \\
& Fund Usage Report Entity \\
& Unit Entity \\
& \\
Employee Entity & Unit Entity \\
Attendance Entity \\
Position Entity \\
Rating Entity \\
Recruitment Entity \\
Selection Entity \\
Employee Submission Entity \\
Facilities and Infrastructure & Unit Entity \\
Supplier Entity \\
Item Type Entity \\
Goods Inventory Entity \\
Movements of goods \\
Filing Entity Entity \\
Goods Maintenance Entity \\
Budget Entity \\
Goods Brand Entity \\
\end{tabular}

2. Technology Architecture

After identifying application architecture, the next step is to propose the development of technology architecture that is owned to improve system performance.

3. Migration Planning

The current system is not completely replaced with a new system, the integration of new system data with the current system is carried out to be able to connect with each other. The integration of this system has a considerable risk if the new system to be used is considered a failure in supporting Cilacap's AMN business. For this reason, before the migration phase is carried out, the company must carry out a trial phase in its use.

4. Milestone

Implementation planning is based on priority needs, adequate budget availability, management and organizational readiness, and HR readiness. The roadmap for the implementation of IS / IT, namely an implementation plan for information system development and information technology for the next 20 years which is used as a reference in order to achieve the vision and mission of the development of IS / IT in the AMN Cilacap environment. The roadmap is also equipped with gradually targeted milestones or achievements. Figure 8 illustrates the intended roadmap and information system development milestones and information technology. 


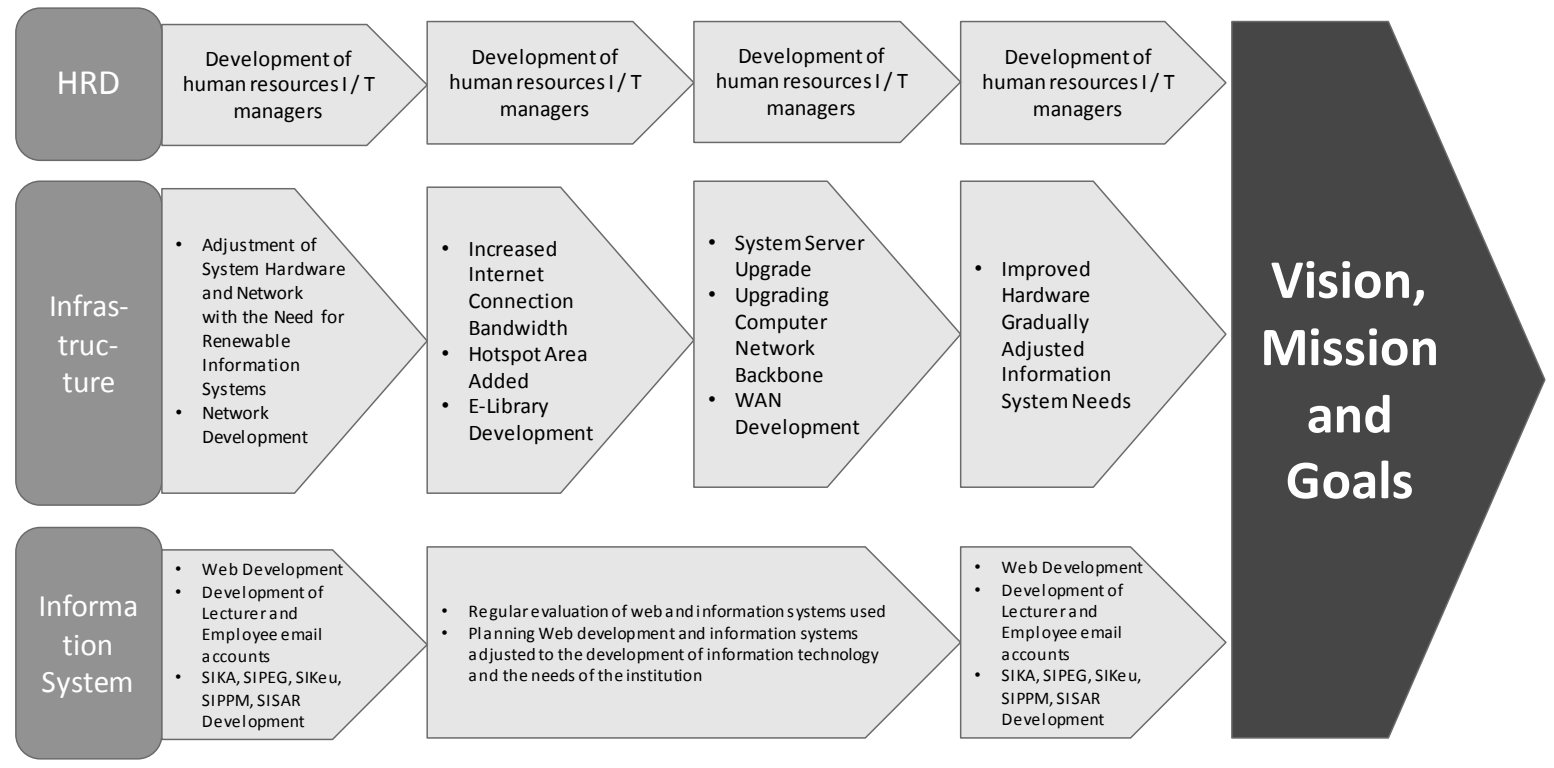

Figure 8. AMN Cilacap Information System Milestone in 2021 - 2040

\section{Conclusions and Recommendations}

\subsection{Conclusions}

The conclusion that can be obtained from the description that has been described is as follows:

1. The final results obtained are a blueprint of EA IS / IT strategic planning as a guide to the development of IS / IT in line with the business processes at AMN Cilacap.

2. The formulation of strategic planning using the EA method resulted in the future strategic planning documentation of the AMN Cilacap. This will be beneficial for management and all academics can control existing resources and increasingly support the improvement and ability to use IS / IT actively and sustainably.

\subsection{Recommendations}

There are still shortcomings in this study, so the suggestions for the next study are:

1. Involving top management in collecting data for the development of IS / IT at AMN Cilacap both by distributing questionnaires and direct interviews so that the system to be developed can be more in line with existing needs and resources.

2. Include risk management factors because this project involves large human and financial resources and relatively long development time. Risk management is needed to minimize the risks that might occur when working on this project.

Considering the rapid development of information technology and its application, it is necessary to consider the development of information and communication technology systems that are used periodically so that these institutions are not too lagging and diminish their competitiveness in addition to producing graduates who are ready for the development of the maritime world at that time.

\section{References}

[1] J. N. Luftman, P. R. Lewis, and S. H. Oldach, "Transforming the enterprise: The alignment of business and information technology strategies," IBM Syst. J., vol. 32, no. 1, pp. 198-221, 2010.

[2] Mardiana and K. Araki, "EA-MDA Model to Resolve is Characteristic Problems in Educational Institutions," Int. J. Softw. Eng. Appl., vol. 4, no. 3, pp. 1-20, 2013.

[3] R. A. Razak, Z. M. Dahalin, H. Ibrahim, N. I. Yusop, and M. K. Kasiran, "Investigation on the importance of enterprise architecture in addressing business issues," 2011 Int. Conf. Res. 
Innov. Inf. Syst. ICRIIS'11, 2011.

[4] B. D. Rouhani, M. N. ri Mahrin, F. Nikpay, and P. Nikfard, "A comparison enterprise architecture implementation methodologies," Proc. - 2013 Int. Conf. Informatics Creat. Multimedia, ICICM 2013, pp. 1-6, 2013.

[5] T. Clark, B. S. Barn, and S. Oussena, "A method for enterprise architecture alignment," Lect. Notes Bus. Inf. Process., vol. 120 LNBIP, pp. 48-76, 2012.

[6] F. R. Morris, J. E. Timmerman, and A. S. Lovvorn, "Seacoast University: the IT factor in moving online," CASE J., vol. 10, no. 1, pp. 3-11, 2014.

[7] M. Plechawska-Wójcik and M. Borys, "the Comprehensive Approach To Students It Research Projects Developing," INTED2016 Proc., vol. 1, no. March, pp. 835-843, 2016.

[8] J. Lapalme, A. Gerber, A. Van Der Merwe, J. Zachman, M. De Vries, and K. Hinkelmann, "Exploring the future of enterprise architecture: A Zachman perspective," Comput. Ind., vol. 79, pp. 103-113, 2016.

[9] C. T. Jensen, O. Cline, and M. Owen, "Combining Business Process Management and Enterprise Architecture for Better Business Outcomes," Ibm.Com/Redbooks, no. Marts, p. 189, 2011.

[10] S. Buckl, A. M. Ernst, F. Matthes, R. Ramacher, and C. M. Schweda, "Using enterprise architecture management patterns to complement TOGAF," Proc. - 13th IEEE Int. Enterp. Distrib. Object Comput. Conf. EDOC 2009, pp. 34-41, 2009.

[11] ISO, IEC, and IEEE, "International Standard ISO/IEC/IEEE 42010:2011 Systems and software engineering - Architecture Description," Iso/Iec/Ieee, vol. 2011, pp. 1-94, 2011.

[12] R. Harrison, "Study Guide: TOGAF 9 Foundation, 2nd Edition," p. 203, 2011.

[13] A. Gerber, P. Kotz, and A. Van Der Merwe, "Towards the Formalisation of the Togaf Content Metamodel Using Ontologies," pp. 54-64, 2011.

[14] Zachman, "EA: The Issue of the Century," 1996.

[15] S. Bondar, J. C. Hsu, A. Pfouga, and J. Stjepandić, "Agile digital transformation of System-ofSystems architecture models using Zachman framework," J. Ind. Inf. Integr., vol. 7, pp. 33-43, 2017.

[16] N. B. Kurniawan and Suhardi, "Enterprise architecture design for ensuring strategic business IT alignment (integrating SAMM with TOGAF 9.1)," Proc. 2013 Jt. Int. Conf. Rural Inf. Commun. Technol. Electr. Technol. rICT ICEV-T 2013, 2013.

[17] T. O. Group and A. R. Reserved, Personal PDF Edition TOGAF Version 9. 2009.

[18] C. Z.a, C. C.a, K. A.S.a, and M. V.b, "Smart Hospital Management System: An integration of enterprise level solutions utilising open group architecture framework (TOGAF)," Proc. - 2010 3rd IEEE Int. Conf. Comput. Sci. Inf. Technol. ICCSIT 2010, vol. 5, pp. 8-15, 2010.

[19] J. Mejia, M. Muñoz, Á. Rocha, and J. Calvo-Manzano, "Trends and applications in software engineering: Proceedings of the 4th International conference on software process improvement CIMPS'2015," Adv. Intell. Syst. Comput., vol. 405, pp. 111-121, 2016.

[20] I. H. A. Wahab and A. Arief, "An integrative framework of COBIT and TOGAF for designing IT governance in local government," ICITACEE 2015 - 2nd Int. Conf. Inf. Technol. Comput. Electr. Eng. Green Technol. Strength. Inf. Technol. Electr. Comput. Eng. Implementation, Proc., pp. 36-40, 2016.

[21] D. P. S. Aithal, "Study on ABCD Analysis Technique for Business Models, business strategies, Operating Concepts \& Business Systems Dr. P. S. Aithal," Int. J. Manag. Soc. Sci., vol. 04, no. 01, 2016. 